\title{
Compatibility of Major U.S. Christian Denominations with Evolution
}

\author{
Joel W. Martin
}

Published online: 20 April 2010

(C) Springer Science+Business Media, LLC 2010

\begin{abstract}
Public school teachers sometimes encounter the sentiment that the study and acceptance of evolutionary theory is contrary to the Christian faith. This perception can pose a significant barrier to the teaching of evolution and other sciences if students assume beforehand that the topic contradicts what they are supposed to believe from a religious standpoint. An informal survey of major Christian organizations and denominations in the United States, based mostly on publicly available statements, indicates that in fact most Christians, as represented by their governing bodies, view evolution as being compatible with their faith. Although on a worldwide basis this is largely a result of the high number (estimated at 1.2 billion) of adherents to Catholicism, even in the United States, where Protestants outnumber Catholics and where anti-evolution sentiment runs high, there is more acceptance than non-acceptance of evolution among Christians, based on statements from their organizing bodies or spokespersons. Protestant groups are divided on the issue, with more "mainstream" denominations (e.g., Lutheran, Methodist, Presbyterian) accepting evolutionary biology as being compatible with their faith, and more fundamentalist or Pentecostal groups denying compatibility or rejecting evolution. Relevant statements from denominations or organizations both pro and con are included.
\end{abstract}

Keywords Evolution · Teaching · Christianity .

Compatibility $\cdot$ U.S. denominations

J. W. Martin $(\bowtie)$

Natural History Museum of Los Angeles County,

900 Exposition Boulevard,

Los Angeles, CA 90007, USA

e-mail: jmartin@nhm.org

\section{Introduction}

One of the persistent misconceptions among the public, especially in the United States, is that evolution is embraced by a mostly secular component of society and is viewed with distrust by persons of faith. This misconception is probably fueled by poll data indicating that, for example, 53\% of both Protestants and Catholics in the U.S. feel that "science and religion are often in conflict," with $41 \%$ of that group referring specifically to evolution as an area of conflict (see page 16 of the results of the Pew Research Center for The People and the Press survey "Scientific Achievements Less Prominent than a Decade Ago: Public Praises Science; Scientists Fault Public, Media" at http://people-press.org/reports/pdf/528.pdf, July $9,2009)$. In that same survey, when asked if science conflicted with their personal religious beliefs, only $56 \%$ of Protestants and $52 \%$ of Catholics said that it did not, compared to $79 \%$ of responders with no stated religious affiliation. Using data from three General Social Surveys in 1933, 1994, and 2000, Mazur (2004: 55) found that "Christian religiosity was the strongest correlate of disbelief in evolution." This perceived divide (secular= pro-evolution, religious $=$ anti-evolution) can be a stumbling block to the teaching of evolution and other sciences, especially if students assume that the topic is going to be contradictory to their religion before hearing what it entails. That science and faith have a relatively long, and relatively harmonious, history (with some obvious exceptions) is usually overlooked. In this article (see also Martin 2010), I present data to dispel the myth that Christians are of a single voice that is opposed to the teaching or acceptance of evolutionary theory.

Most Christians worldwide, as represented by statements from their governing bodies (see later), are in fact accepting 
of biological evolution as being fully compatible with their faith. This claim is easily supported by referring to the Catholic Church, the world's largest Christian organization. Catholics (including Roman Catholics and Eastern Orthodox) constitute some 1.2 billion of the estimated 2.2 billion people worldwide who count themselves as Christians (Barrett et al. 2001, Adherents.com website). That's more than half of all Christians and roughly $1 / 6$ of the entire world population. Apart from the Galileo affair and a few other notable episodes, the Catholic Church has a long history of accepting the findings of science, including evolutionary biology, as revelations of how God's world works.

However, because creationism (including intelligent design) is predominantly a Protestant and predominantly a U.S. phenomenon (see Numbers 2006 and Curry 2009 for discussions of creationism in other parts of the world), we should look beyond the Catholic Church to determine the position of other Christian organizations regarding evolution. In the U.S., there are slightly more Protestants than Catholics (estimates vary from approximately $52-70 \%$ Protestant to $24-44 \%$ Catholic). ${ }^{1}$ Additionally, some of today's evangelical Christian groups have expressed the opinion, despite their historical roots, that Catholics are somewhat questionable Christians for a variety of reasons (recall that differences between Protestants and Catholics run long and deep). Protestant groups are more divided on the issue of compatibility of their faith with evolution (see below). For this article, I searched for statements about church doctrine and evolution from some of the larger Christian (Catholic and Protestant) groups in the United States, and in some cases sent queries to their national headquarters, to gather the information presented below (see also Martin 2010). To answer the question "how do most Christians perceive evolution and their faith?" I need first to address the various estimates of membership within the many divisions of Christianity.

It is difficult to obtain accurate estimates of the number of members of the many religions of the world, and this is true for Christianity as well. Numbers depend on which

\footnotetext{
${ }^{1}$ For example, Gibbons (2007, chart on p. 22; see full reference in footnote 3 below) estimates 52\% Protestant and only 24\% Roman Catholic for the United States. The Pew Forum on Religion and Public Life's U.S. Religious Landscape Survey "Religious Composition of the U.S." (2007, http://religions.pewforum.org/pdf/affiliations-alltraditions.pdf) is similar $(51 \%$ and $24 \%)$. Other references (e.g., Ontario Consultants on Religious Tolerance website at http://www. religioustolerance.org/) give higher figures for Catholics. That site also contains data from a variety of polls, at: http://www.religious tolerance.org/ev_publi.htm, and a link to a list of what various

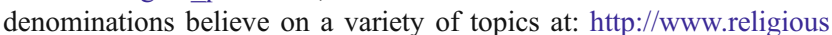
tolerance.org/ev_denom.htm
}

survey you consult and sometimes on which definition you use. There is no single, universally accepted definition of what a Christian is, and indeed one source (the website of the Ontario Consultants on Religious Tolerance) offers approximately 40 different definitions of the word Christian. The Central Intelligence Agency (CIA) Factbook on the world's population ${ }^{2}$ listed the following estimates of the world's Christians as of October 2008: total world population 6,706,993,152; Christians 2,234,770,118 (33.32\% of world total); Roman Catholics 1,139,518,136 (16.99\%); Protestants 387,664,204 (5.78\%); Orthodox 236,756,858 (3.53\%); Anglicans 83,837,414 (1.25\%). This breakdown into four major groups of Christian denominations is one of many classifications that could be used. Other references list four to eight "meta-groups" of Christians, expanding the above list to include Eastern Orthodox, Oriental Orthodox and Assyrian, Restorationist, and Pentecostal movements as separate groups. Still other estimates ${ }^{3}$ list a larger overall number of Protestants, from 500 to 700 million. Some references divide Christians into the following large categories, with estimated numbers worldwide in parentheses: Catholicism (1.2 billion), Protestantism (700 million), Eastern Orthodoxy (260 million), Oriental Orthodoxy (79 million), Anglicanism (77 million), Nontrinitarianism (23 million), and Nestorianism (1 million). These numbers suggest roughly 2.34 billion Christians on earth, a number that is close to the CIA estimate above. For the U.S., somewhere between 76.5\% (American Religious Identity Study [ARIS], 2001) and $82 \%$ (Pew Research Center, 2002; 49, question 18) (see Adherents.com website) of the population identifies itself as Christian (= roughly 225 to 246 million). I have

\footnotetext{
${ }^{2}$ CIA World Factbook, United States Government Central Intelligence Agency. https:/www.cia.gov/library/publications/the-world-factbook/ geos/xx.html\#People

${ }^{3}$ Other sources for estimates of the number of Christians overall and within each denomination include: Time Almanac (2002, p. 435); The on-line encyclopedia Wikipedia (as of October 2008); Yearbook of American and Canadian Churches published by the National Council of Churches USA, with some data repeated on their website at: http:// www.ncccusa.org/members/index.html); Diamond, Larry Jay, Marc F. Plattner, and Philip J. Costopoulos (editors), 2005, World Religions and Democracy (A Journal of Democracy Book); Johns Hopkins University Press, 262 pp; McGrath, Alister E., 2006, Christianity: An Introduction; Hinnells, John R., 2005, The Routledge Companion to the Study of Religion; Barrett, David, et al., 2001, "World Christian Encyclopedia: A comparative survey of churches and religions-AD 30 to 2200," Oxford University Press; Your Guide to the Religions of the World, BBC World Service, online at http://www.bbc.co.uk/; Largest Religious Groups in the United States of America (part of Major Religions of the World Ranked by Number of Adherents); online at: http://www.adherents.com; and Gibbons, David, 2007, Faiths and Religions of the World: The History, Culture, and Practice of Beliefs, Thunder Bay Press, San Diego, 160 pp.
} 
included for this article the Episcopal Church (2.3 million) and the largest U.S. Orthodox church, the Greek Orthodox Archdiocese of America (1.5 million). Mormonism (Church of Jesus Christ of Latter Day Saints), which is sometimes treated as a Christian group apart from Protestant denominations, is not treated here; the Mormon Church (with an estimated 15 million members) is, however, generally supportive of modern science, including evolution, as compatible with its faith. ${ }^{4}$ Similarly, the Unitarian Universalist Association, which traces its roots to Christianity, is not treated here, although the UUA is also generally supportive of evolution. ${ }^{5}$

Within the large (400-700 million) Protestantism category, the major "families" of denominations include Baptist, Methodist, Reformed churches (including Calvinism, Presbyterianism, and Congregationalism), Lutheranism, Anabaptists (including Mennonites, Quakers, Church of the Brethren, Hutterites, Amish, and others), Pentecostalism (including Assemblies of God, Church of God in Christ, International Church of the Foursquare Gospel, The Pentecostal Mission, Apostolic Church, and many others), "non-denominational evangelicalism" (including Calvary Chapel and the Vineyard church movements), and Restorationists (including Seventh-day Adventists and Church of Christ). The number of members in each group varies widely depending on which survey one consults, how the survey was conducted, and how each group counts and reports membership. Nearly all of the above large categories or denominations are further subdivided, to the point that there are more than 30,000 Christian organizations (groups, branches or denominations) worldwide, and more than 1,200 in the U.S. alone (see notes 1 and 3).

Not surprisingly, it is also difficult to get a firm handle on what each of these groups believes concerning the

\footnotetext{
${ }^{4}$ Letter from Brigham Young University professor Wilford Hess and 19 other BYU faculty, citing, among other sources, the 1992 Encyclopedia of Mormonism, published 8 June 2000 (reprinted in "Mormonism and Evolution" on the Mormonism Research Ministry site by Bill Mckeever, at: http://www.mrm.org/evolution). The letter includes the statement: "Mormonism emphatically does not fit into the theological mold of modern creationism. The creationists' concept of a single triune and sovereign deity who spoke all time, energy, matter and space into existence from nothing (i.e. ex nihilo) is flatly rejected in LDS doctrine." On the other hand, see the February 28, 2006, article "No definitive LDS stance on evolution, study finds" by Carrie A. Moore in the Deseret News at: http:/www.deseretnews.com/article/ $1,5143,635188399,00 . h t m l$

${ }^{5}$ The June 1982 General Assembly of the UUA "...urges the Board of Trustees and President of the Association, member societies, and Unitarian Universalists in the United States to: ... oppose efforts to compromise the integrity of public school teaching by the introduction of sectarian religious doctrines, such as "scientific creationism," and by exclusion of educational materials on sectarian grounds".
}

interaction of science and faith, or more specifically about creationism and evolution. Some offer clear statements about their beliefs on this topic while others do not, and even a clear statement should not be taken to imply that all members adhere to that particular stance. In fact, it's a serious mistake to assume that all members of any given faith adhere completely to the tenets and beliefs set by their leaders. Any large group will contain a diversity of beliefs and opinions. Within my own denomination (the Presbyterian Church USA [PCUSA]) - and in fact even within the relatively small number of members in my own local church - it is easy to find quite divergent views on a wide range of theological issues. But since we cannot survey all of the 225 to 246 million Christians in the U.S. (but note that some social surveys exist; see Mazur 2004), for now I have relied on statements by the governing bodies and spokespersons for these groups.

Listed below are the larger Christian denominations in the United States, followed by the approximate size of the group (estimated number of members). The membership estimates are the average of the high and low numbers from the following sources: $\mathrm{T}=$ Time Almanac (2002); $\mathrm{Y}=$ Yearbook of American and Canadian Churches (2007); $\mathrm{A}=$ Adherents (Largest Religious Groups in the United States of America; part of Major Religions of the World Ranked by Number of Adherents); US=reports of the U.S. Census Bureau; $\mathrm{W}=$ Wikipedia (see note 3 ). For each of the denominations or groups, I have included information on their stance on evolution or creationism/intelligent design, usually in the form of publicly available statements and the dates of those statements, key phrases from those statements, and (in some cases) the name of the person responsible for the statement. Again, these statements should not be taken to mean that every member of the represented organization is in agreement with (or is even aware of) the statement. For many religious organizations, no such statements exist, and no stance on this issue is taken or implied one way or the other ${ }^{6}$ (see also Sager 2008). Table 1 summarizes these positions and membership estimates.

\footnotetext{
${ }^{6}$ Additional statements from a wide variety of religious groups (Christian and non-Christian) that support the acceptance of evolutionary biology as being compatible with their faith can be found on the website of the National Center for Science Education (www.ncse. com). These organizations include: American Jewish Committee, American Jewish Congress, American Scientific Affiliation, Central Conference of American Rabbis, Episcopal Church, Presbyterian Church USA, Lexington Alliance of Religious Leaders, Lutheran World Federation, Roman Catholic Church, United Church Board for Homeland Ministries, Unitarian Universalist Association, United Methodist Church, and others. See especially the NCSE document "Voices for Evolution" (Sager 2008).
} 
Table 1 Summary of the positions of selected Christian organizations or denominations on evolution and creationism, arranged by decreasing size (estimated membership)
Totals at bottom reflect estimated membership numbers in the United States. See text for details

${ }^{\mathrm{a}}$ Assumed position based on views of other Methodist (for AME), Baptist (for NBC USA), or Pentecostal groups (for New Apostolic, ICFG, and COGIC). $+=$ no current estimate for membership number at this time.
Denomination or movement

Accepting of evolution as being compatible with their faith

Position unknown or unclear

\section{Yes}

Roman Catholic

Southern Baptist Convention

United Methodist

National Baptist Convention USA

Church of God in Christ

Evangelical Lutheran Church of America

African Methodist Episcopal Church (AME)

Church of Christ

No

Unclear

International Circle of Faith

Anabaptists

Presbyterian Church (PCUSA)

Calvary Chapel

Church of God (Cleveland)

Yes

No

$\mathrm{No}^{\mathrm{a}}$

$\mathrm{No}^{\mathrm{a}}$

Yes

Yes $^{\mathrm{a}}$

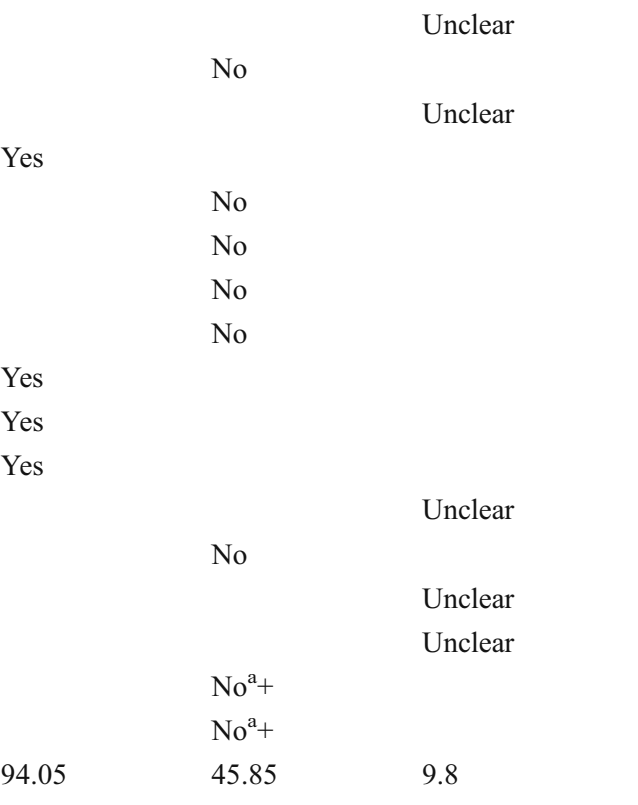

\section{Major U.S. Denominations and their Stance on Creationism and Evolution}

Catholic and Eastern Orthodox Churches

\section{Roman Catholic Church 66.6 million $\left[62.0^{T}-71.2^{A}\right]$}

- $\quad$ 1996. Pope John Paul II, speaking at the annual meeting of the Pontifical Academy of Sciences:

"Today, almost half a century after the publication of the Encyclical, fresh knowledge has led to the recognition that evolution is more than a hypothesis. It is indeed remarkable that this theory has been progressively accepted by researchers, following a series of discoveries in various fields of knowledge. The convergence, neither sought nor fabricated, of the results of work that was concluded independently is in itself a significant argument in favor of this theory."

- 2006. Vatican newspaper L'Osservatore Romano, article by Fiorenzo Facchini: "'intelligent design' is not science and teaching it alongside evolutionary theory in school classrooms only creates confusion."

- 2009. Archbishop Gianfranco Ravasi, head of the Pontifical Council for Culture (The Telegraph [UK], 11 February 2009). (From Andy Coghlan's article "Vatican Backs Darwin, Dumps Creationism" in the February 11, 2009, New Scientist "Short Sharp Science" news blog.) Archbishop Ravasi noted that acceptance of evolution could be traced to St. Augustine and St. Thomas Aquinas, adding:

"What we mean by evolution is the world as God created it."

Note: The membership figure used in the text, 1.2 billion, is the estimated global figure; for the United States, the estimate is approximately 67 million (see Barrett et al. 2001, and the "Adherents.com" website). Fiorenzo Facchini, author of the 2006 article and a professor at the University of Bologna, lamented that 
certain American creationists had brought the debate back to the "dogmatic" 1800 s and said their arguments were not science but ideology.

\section{Greek Orthodox Archdiocese of America 1.75 million} $\left[1.5^{Y, A}-2.0^{T}\right]$

- 2006. A Theology of Nature: An Introduction (first published in 1991), by Metropolitan Paulos Mar Gregorios of the Orthodox Syrian Church of the East, posted on the website of the Greek Orthodox Archdiocese of America and thus assumed (by me) to be endorsed by the GOAA:

"The created order is a space-time process, or rather a procession, orderly and sequential, journeying through life from something to something. Life is an important aspect of that procession from origin to perfection; it is through the evolution of life that the procession moves forward" (referring to the writings of Gregory of Nyssa in the fourth century).

\section{Episcopal/Anglican Communion}

\section{Episcopal Church 2.3 million $\left[2.2^{Y}-2.4^{T}\right]$}

- 1981. The 74th Annual Council of the Diocese of Atlanta, in formal action on January 31, 1981, acted without a dissenting vote to oppose by resolution any action by the Georgia Legislature to impose the teaching of Scientific Creationism on the public school system. In an eloquent "Pastoral Statement on Creation and Evolution," the Rt. Rev. Bennett J. Sims, Episcopal Bishop of Atlanta, wrote:

"If the world is not God's, the most eloquent or belligerent arguments will not make it so. If it is God's world, and this is the first declaration of our creed, then faith has no fear of anything the world itself reveals to the searching eye of science."

- 1982. Statement from the 67th General Convention of the Episcopal Church:

“...the House of Bishops concurring, That this 67th General Convention affirm its belief in the glorious ability of God to create in any manner, and in this affirmation reject the rigid dogmatism of the 'Creationist' movement, and be it further resolved, That we affirm our support of the scientists, educators, and theologians in the search for truth in this creation that God has given and entrusted to us." Additionally, "clergy and scientists from both the Catholic and
Evangelical traditions in Anglicanism [the US branch of which is the Episcopal Church] have accepted evolution from Darwin's time to the present. In a resolution passed by the General Convention in 1982, the Church affirmed the ability of God to create in any form and fashion, which would include evolution."

- 2006. Statement from the 75th General Convention of the Episcopal Church:

"Resolved, That the theory of evolution provides a fruitful and unifying scientific explanation for the emergence of life on earth, that many theological interpretations of origins can readily embrace an evolutionary outlook, and that an acceptance of evolution is entirely compatible with an authentic and living Christian faith..." (Resolution A129: Affirm Creation and Evolution).

Note: See "The Episcopal Church: Science, Technology, and Faith" at http://www.episcopalchurch.org/19021 58398 ENG HTM.htm.

\section{Baptist Churches}

\section{Southern Baptist Convention 16.0 million $\left[15.7^{T}-16.3^{Y}\right]$}

- 2005. Article in Time magazine (August 15, 2005) quoting R. Albert Mohler Jr., president of Southern Baptist Theological Seminary, Louisville, KY. The website for the issue of the Baptist Press with this article is www.bpnews.net/bpnews.asp? ID $=21375$ :

"Evangelical Christianity and evolution are incompatible beliefs that cannot be held together logically within a distinctly Christian worldview" (view attributed to Mohler in the article; not a direct quote).

- 2009. Mohler was also quoted more recently (February 15, 2009) in the online e-newsletter Christian Post (http:// www.christianpost.com/article/20090215/evolution-andchristianity-impossible-toreconcile-says-evangelicaltheologian/index.html) as saying that:

"I find it impossible to reconcile the two" and that "There is no way for God to intervene in the process and for it to remain natural." Yet he is also quoted there as saying that "No Conservative Christian should deny there is a process of change that is evident within the animal kingdom. And there is even a process of natural selection that appears at least to be natural." 
National Baptist Convention, USA 6.6 million $\left[5.0^{Y}-8.2^{T}\right]$

Note: The NBC USA was queried in October 2008, but no reply was received. I am assuming their position is similar to the sentiments of the Southern Baptists (see above).

\section{American Baptist Churches USA 1.3 million}

Note: According to Roy Medley (General Secretary, ABCUSA), "We have no policy statement on the issue" (personal e-mail reply, 2010). Thus, they are listed in the "unknown" category in Table 1. The membership estimate is from their website (http://www.abc-usa.org/default.aspx).

Methodism

United Methodist Church 10.0 million $\left[8.0^{Y}-12.0^{W, A}\right]$

- 1984. A resolution passed at the 1984 Annual Conference of the UMC in Iowa specifically spoke out against creationism:

"Whereas, 'Scientific' creationism seeks to prove that natural history conforms absolutely to the Genesis account of origins; and,

Whereas, adherence to immutable theories is fundamentally antithetical to the nature of science; and,

Whereas, 'Scientific' creationism seeks covertly to promote a particular religious dogma; and,

Whereas, the promulgation of religious dogma in public schools is contrary to the First amendment to the United States Constitution; therefore,

$B e$ it resolved that The Iowa Annual Conference opposes efforts to introduce 'Scientific' creationism into the science curriculum of the public schools."

- 2004. The UMC has a 2004 statement on science and technology that would encompass evolution (from the UMC website at www. umc.org, which in turn comes from The Book of Discipline of the United Methodist Church, copyright 2004 by The United Methodist Publishing House).

"We recognize science as a legitimate interpretation of God's natural world. We affirm the validity of the claims of science in describing the natural world, although we preclude science from making authoritative claims about theological issues.... Science and theology are complementary rather than mutually incompatible. We therefore encourage dialogue between the scientific and theological communities and seek the kind of participation that will enable humanity to sustain life on earth and, by God's grace, increase the quality of our common lives together."
- 2008. At the 2008 UMC General Conference in Fort Worth, Texas, three resolutions or petitions were passed, including a revised wording of the earlier resolution titled "God's Creation and the Church" (reported in the online May 28, 2008, issue of EthicsDaily.com, "Methodists Oppose Teaching of Creationism, Intelligent Design" by Bob Allen, at http://www.ethicsdaily. com/news.php?ViewStory=12668; see also http://www. umportal.org/article.asp?id=3869. Excerpts from two of the petitions are below:

\section{Evolution and Intelligent Design (80839-C1-R9999)}

"therefore be it resolved that the General Conference of the United Methodist Church go on record as opposing the introduction of any faith-based theories such as Creationism or Intelligent Design into the science curriculum of our public schools."

Science and Technology (80050-C1-160.E)

“...science's descriptions of cosmological, geological, and biological evolution are not in conflict with theology.... We find that as science expands human understanding of the natural world, our understanding of the mysteries of God's creation and word are enhanced."

Note: Concerning membership numbers for the UMC, the "Adherents.com" website gives a combined "Methodist/ Wesleyan" estimate (for largest denominational families in U.S.) of 14.15 million for 2001 and 19.97 million for 2004, but on a separate page lists 8.2 million for the UMC among the "Largest Religious Bodies in the U.S." More recently, the UMC's General Council on Finance and Administration website (http://www.gcfa.org/analysis.html) has a map of the U.S. with regional membership numbers, current as of December 31, 2007. Adding all of the membership figures gives approximately 7.8 million. Thus, 10 million may be too high for the UMC estimate.

African Methodist Episcopal Church (AME) 3.8 million $\left[2.5^{T, Y}-5.0^{W, A}\right]$

Note: No reply was received to my query in October 2008. I am assuming that the AME beliefs are aligned with the larger UMC above, as its roots are within the Methodist Church beliefs and doctrines. Membership estimates on various websites have changed in recent years.

Presbyterianism

Presbyterian Church USA 3.3 million $\left[3.0^{Y}-3.6^{T, U S}\right]$

- 1998. $85 \%$ of Presbyterian pastors (responding to a November 1998 PCUSA survey on Science, Technology, 
and Faith [reported in The Presbyterian Panel]) agreed with the statement below:

"Evolutionary theory is compatible with the idea of God as Creator."

- 2000. See also "Evolution Not an Option: It Is Essential to Faithfulness" (SciTech 9, no. 2 [2000]), by James B. Miller, then-President of the Presbyterian Association on Science, Technology, and the Christian Faith.

- 2002. The statement from the 214th General Assembly, Columbus, $\mathrm{OH}$ :

"Reaffirms that there is no contradiction between an evolutionary theory of human origins and the doctrine of God as Creator" (Resolution Item 09-08, 2, p. 495).

- Undated Evolution Statement. The statement, reiterating a 1969 statement (GA Minutes 1969: 59-62) by the PCUSA Office of Theology and Worship, is available on the PCUSA website (www.pcusa.org/theologyand worship/science/evolution.htm):

"Neither Scripture, our Confession of Faith, nor our Catechisms, teach the Creation of man by the direct and immediate acts of God so as to exclude the possibility of evolution as a scientific theory."

Note: The PCUSA should not be confused with the more conservative Presbyterian Church in America (PCA), currently estimated at 300,000 to 500,000 members, mostly in the southeastern United States and especially in Atlanta. The PCA does have a "Report of the Creation Study Committee" available on their website that indicates that they could not reach consensus on this subject.

Congregationalism

\section{United Church of Christ 1.3 million $\left[1.2^{Y}-1.4^{T}\right]$}

- 1992. United Church Board for Homeland Ministries (statement titled "Creationism, the Church, and the Public School”) at http://ncseweb.org/media/voices/ united-church-board-homelandministries:

"We acknowledge modern evolutionary theory as the best present-day scientific explanation of the existence of life on earth; such a conviction is in no way at odds with our belief in a Creator God, or in the revelation and presence of that God in Jesus Christ and the Holy Spirit."

- 2008. Rev. John H. Thomas, General Minister and President, United Church of Christ, "A New Voice
Arising: A Pastoral Letter on Faith Engaging Science and Technology" (January 2008) (www.ucc.org/notmutually-exclusive/pdfs/pastoral-letter.pdf):

"Evolution helps us see our faithful God in a new way. Evolution also helps us see ourselves anew, as creatures who share a common origin with other species."

Lutheranism

Evangelical Lutheran Church in America 5.0 million $\left[4.8^{Y}-5.2^{T, U S}\right]$

- Lutheran World Federation, statement on the web at www.lutheranworld.org/News/LWI/EN/1823.EN.html. See also Edwin A. Schick, "Evolution" in The Encyclopedia of the Lutheran Church, vol. 1, ed. J. Bodensieck (Minneapolis, MN: Augsburg Publishing House, 1965):

"In whatever way the process may be ultimately explained, it has come about that an idea which has been most thoroughly explored in the field of biology (lower forms of life evolving into higher) has by means of organismic analogy found universal application. Phenomena thus accounted for range from physical realities (evolution of the atoms and expanding galaxies) to man and his social experience (the evolution of cultural values) including his understanding of time and history (the evolutionary vision of scientific eschatology)."

Note: The Lutheran World Federation statement should not be taken as representative of all Lutheran congregations. The largest Lutheran group in the United States is the Evangelical Lutheran Church in America (ELCA), which, with 5 million members, is also the fifth largest "mainline" or "historical" Protestant denomination in the nation. On the ELCA website under the heading "Creation vs. Evolution," the following statement appears:

"The ELCA does not have an official position on creation vs. evolution, but we subscribe to the historical-critical method of biblical interpretation, so we believe God created the universe and all that is therein, only not necessarily in six 24-hour days, and that God actually may have used evolution in the process of creation. In fact, to deny the possibility that evolutionary processes were used is seen by some as an attempt to limit God's power. 'Historical criticism' is an understanding that the Bible must be understood in the cultural context of the times in which it was written." 
Lutheran Church-Missouri Synod 2.5 million $\left[2.4^{Y}-2.6^{T}\right]$

Note: In stark contrast to the ELCA, the Lutheran ChurchMissouri Synod is strongly against the idea of compatibility of evolution and faith; their website formerly referred readers to a 1977 document favoring strict literal creationism and now includes a more recent pro-ID statement, "What About Creation and Evolution," by former LCMS president Dr. A. L. Barry (www.lcms.org/graphics/assets/ media/LCMS/wa_creation-evolution.pdf). The third largest Lutheran group in the United States, the Wisconsin Evangelical Lutheran Synod $(\sim 390,000)$, is not treated here.

\section{Anabaptists}

\section{Combined Anabaptist Groups 4.5 million [4.0-5.0 $\left.0^{W, A}\right]$}

Note: The American religious groups often combined under the heading "Anabaptist" (including Mennonites, Brethren in Christ, Amish, Hutterites, Church of the Brethren, Open Brethren, and sometimes the Religious Society of Friends [Quakers]) are primarily concerned with how Christians should address the many social ills facing humanity and bring about peace in the world. As such, they have no stated position on science, faith, evolution, and creationalthough I have corresponded with individual members who do have a position on the issue-and therefore I am unable to attribute to these groups one particular stance or the other. Some classifications of religious organizations include Baptists (which I have treated separately above) among the Anabaptist groups. Estimates of membership vary widely and are not found in one place; the above estimate is combined from adding estimates for each the above groups.

\section{Pentecostalism}

\section{Assemblies of God, USA 2.65 million [2.5 $\left.5^{T, U S}-2.8^{Y}\right]$}

- 1977. The Assemblies of God USA website (at http:// ag.org/top/Beliefs/Position_Papers/index.cfm) lists a number of position papers including "The Doctrine of Creation," adopted by the Assemblies of God General Presbytery in August 1977 and containing the statement below. Another article in their section on beliefs is titled "Creationism" and was endorsed by the church's Commission on Doctrinal Purity and the Executive Presbytery; it states that "Assemblies of God believers hold that the Genesis account should be taken literally."

"The Bible record of creation thus rules out the evolutionary philosophy which states that all forms of life have come into being by gradual, progressive evolution carried on by resident forces. It also rules out any evolutionary origin for the human race, since no theory of evolution, including theistic evolution, can explain the origin of the male before the female, nor could it explain how a man could evolve into a woman."

\section{Church of God (Cleveland) 2.9 million $\left[0.8^{T, U S}-5.0^{W, A}\right]$}

- 1980. Resolution on Creationism (on their website www.churchofgod.org/under"Beliefs/Resolutions"):

"WHEREAS secular humanism and anti-God philosophies are being taught in our public educational systems; and WHEREAS there is a need for God's people to unite against the teaching of evolution as a scientific fact; THEREFORE BE IT RESOLVED that we give our full support to the principle that where evolution is taught in our public schools, provision be made for teaching the Biblical alternative of creation."

Note: This refers only to the Church of God with international offices in Cleveland, Tennessee. Estimates of membership vary widely.

\section{Church of God in Christ 5.5 million $\left[5.5^{Y}\right]$}

Note: Although the COGIC separated from the Assemblies of God, its beliefs remain firmly Pentecostal and in line with the AOG (see http://cogic.net/cogiccms/default/cogichistory/what-we-believe/); it is therefore listed as not accepting evolution as compatible with its faith in Table 1.

\section{International Circle of Faith 5.5 million}

- 2008. Dr. Bernie L. Wade, Chancellor, International Circle of Faith Colleges and Seminaries (personal communication, December 26, 2008 e-mail):

"The position of the International Circle of Faith concerning creation is biblical creationism. Biblical Creationism is the belief that the biblical record of creation is true. The biblical creationist believes that God created the entire universe out of nothing, by the power of His word.... We believe the first chapter of Genesis describes real events and that the world underwent growth and development during its creation. Further, the human race is unique, the crown of creation. This includes a historical Adam and Eve and a historical fall from grace."

Note: The only estimate I found for ICOF membership was 10.9 million worldwide; I have not received a 
membership figure for within the United States, and so I am using half of that figure as my estimate here. The sole source was far too high on other estimates; the same may be true here. Other Pentecostal churches possibly with large memberships, including the New Apostolic Church and the International Church of the Foursquare Gospel, did not respond to my queries, and no statements could be found. It seems unlikely that any of these would be generally supportive of evolution, given that all are Pentecostal congregations and thus assumed (by me) to be more similar to the Assemblies of God, Church of God, and ICOF positions above. Thus, ICOF is listed as not being accepting of evolution as compatible with its faith in Table 1, but without membership estimates.

Restorationism

Seventh-day Adventists 0.9 million $\left[0.8^{T, U S}-15.0^{W}\right]$

- 2004. The International Faith \& Science Conferences 2002-2004 report of the Organizing Committee to the General Conference Executive Committee through the office of the General Conference President, September 10, 2004. From the "Fundamental Beliefs" section of the Seventh-Day Adventists website (www.adventist.org/):

"We strongly endorse the document's affirmation of our historic, biblical position of belief in a literal, recent, six-day Creation" (from their response statement to "An Affirmation of Creation" on the above website).

Note: Membership estimates ranged extremely widely, from 0.8 to 15 million, for this group. However, most sources used 0.8 to 0.9 million; I am using the higher of these two figures. Seventh-day Adventists have a long history as confirmed young-earth creationists; members, most notably George McReady Price, were responsible for some of the books on young-earth geology or "flood geology" early in the twentieth century.

Church of Christ 3.3 million $\left[1.5^{U S, Y}-5.0^{W}\right]$

Note: This treatment is restricted to the "restorationist" Church of Christ group in America, as opposed to more than 20 other groups that share "Church of Christ" as part of their name (see, for example, the Wikipedia entry on "Church of Christ"). A difficult group to define, the Church of Christ movement can also include churches by the name of "Disciples of Christ" and simply "Christian Church." Individual churches are autonomous, not denominational, and thus there is no central organizing body. The website "Churches of Christ Online" (at http://cconline.faithsite. com/) did not have a science/faith statement on it as of August 2009. Links provided there lead me to think that the overall Church of Christ position does not embrace evolution as compatible with their beliefs; this might be incorrect, and so I have placed them in the "unclear" category in Table 1.

Non-denominational Evangelicalism

\section{Calvary Chapel 3.3 million}

Note: Calvary Chapel and the Vineyard (below) are best described as non-denominational church movements or fellowships. Individual congregations have some flexibility in their stated beliefs and practices. Because of this flexible structure, the primary website for Calvary Chapel states that there is "no central headquarters or organization," and the reader is directed to the nearest Calvary church. I queried the original Calvary Chapel in Costa Mesa, California, but did not receive a reply. The main website (at www4. calvarychapel.com/) states that Calvary Chapel is "focused on the inerrancy of the Bible;" Calvary is also described as a "Bible-believing, evangelical church" (from the "Calvary Chapel Distinctives" written by founding pastor Chuck Smith). These statements, and Pastor Smith's notes on the Calvary website asking why "natural selection today creates a deterioration and mongrelization of a species, rather than a highly developed form," indicate a leaning away from seeing evolution as part of God's creation. In 2009 several Calvary Chapels hosted anti-evolution workshops or conferences associated with Ken Ham's creationist "Answers in Genesis" group. Thus, I have listed Calvary in Table 1 as being opposed to the idea of compatibility between evolution and its faith.

Calvary does not maintain membership numbers, but there are approximately 1,100 Calvary Chapels in the United States, with membership ranging from only 20-30 families up to 10,000-15,000 members (personal communication, Calvary Chapel Outreach Fellowship Office, April 2009). The 3.3 million is based on my arbitrarily using a figure of 3,000 attendees as an average for each of the 1,100 churches.

\section{The Vineyard 0.2 million}

Note: The Vineyard, which broke away from the Calvary movement (above) in the early 1980s, is similar in allowing a diversity of worship styles and approaches, but it is perhaps more diverse and less constrained than Calvary. Within the Vineyard one can find a wide range of stances on the topic of evolution and creation, from liberal or progressive advocates who see evolution as an act of and expression of God to more evangelical advocates who 
would not embrace that view (personal communication, Kris Miller, The Vineyard USA National Office, October 2008). For these reasons, I have listed The Vineyard movement as "unclear" in Table 1. The membership estimate $(150,000$ to 200,000$)$ was given to me by Pam Trautmann of the Vineyard National Office (personal communication, April 2009).

\section{Christian "Megachurches"}

Note: A relatively recent phenomenon in Protestant Christianity is the rise of extremely large, usually nondenominational churches, particularly in the United States. The term "megachurch" has sometimes been applied to those that see 2,000 or more attendees per week. These churches tend to be evangelical or Pentecostal, and they may be independent of mainline Protestant denominations that are similar in name. Because these churches probably constitute a significant (but currently unknown) percentage of the U.S. population of Christians, some mention should be made of them here. A list of the top 100 churches (ranked by size) is published each fall by Outreach magazine (http://www.outreachmagazine.com/top_100. asp). I queried each church that appeared in the 2008 top 10 list about the compatibility of their faith with evolutionary biology, and the results are below. The name of the church is followed by the number of weekly attendees and their position (if known) based on their reply or on known affiliations.

1. Lakewood Church (Houston), 43,500 (No reply)

2. Second Baptist (Houston), 23,659, No (affiliated with Southern Baptist Convention)

3. North Point Community Church (Alpharetta, Georgia), 22,557, Unknown (e-mail indicating a broad acceptance of, and appreciation for, diversity)

4. Willow Creek Community Church (Illinois), 22,500 (No reply)

5. Life Church (Edmond, Oklahoma), 20,823, No ("We believe in creation plain and simple"; e-mail from Randy Coleman, August 24, 2009),

6. West Angeles Cathedral (Los Angeles), 20,000, No (affiliated with Church of God in Christ)

7. Fellowship Church (Grapevine, Texas), 19,913 (No reply)

8. Saddleback Church (Lake Forest, California), 19,414, No (affiliated with Southern Baptist Convention)

9. Calvary Chapel Fort Lauderdale (Florida), 18,000, No (affiliated with Calvary Chapels)

10. Potter's House (Dallas), 17,000, No (described as a fundamentalist Pentecostal Church)

The above numbers are not included in Table 1. Some of these churches, such as those affiliated with the
Southern Baptist Convention (Second Baptist, Saddleback) or with Calvary Chapel (Calvary Chapel Fort Lauderdale) may have been included in the membership estimates of mainstream denominations given earlier. There is also a lot of volatility in the membership of these large churches; the number 6 and 7 churches on the 2008 list did not make the top 10 in 2007. Because most of these churches, and indeed most of the top 100 on the Outreach list, would fit most comfortably in the "No" column of Table 1, these churches would increase the total for that category.

\section{Discussion}

There are a number of important caveats that must be considered when comparing the data summarized in Table 1.

First, as noted earlier, it is difficult to find accurate estimates of membership numbers for many religious groups and organizations. Some groups do not maintain membership figures, some use attendance figures, and some have no central governing body or headquarters. The various sources I used for membership estimates, mostly books and websites, differ in their estimates and even in which groups are included; a "large" group mentioned in one volume might not be included in another or might appear under a different name. Some denominations did not respond to my queries, and some websites and related documents I located appear to be old and might not reflect current thinking.

Second, not all of the estimated 1,200 Christian denominations in the U.S. are listed here or anywhere else. The sheer number of Christian groups means that there are likely to be some large groups not known to me and thus not represented here. Denominations have come and gone over the years, especially in the U.S. Names have changed, groups have merged and split, and there is apparently no single source that tracks all of these changes, although several do a respectable job of maintaining lists of U.S. denominations, and I've attempted to consult all of these sources (see notes).

Third, not all groups have a statement or position on what they believe as concerns science, faith, and evolution. Some offer clear statements about their beliefs on this topic while others do not, and some offer statements that are slightly ambiguous.

Fourth, many Christians in the U.S. attend large "megachurches," several of which are non-denominational (see above). This unknown but undoubtedly significant number of Christians probably is not represented in the membership counts of mainstream denominations, although some of them are (see earlier). 
Fifth, and perhaps most importantly, we cannot assume that all members of a given denomination agree with, or are even aware of, the "official" position of the group to which they belong. Such statements, if they exist, might not reflect the opinions of, and might not even be known by, the general membership of the group. I know Presbyterians who are creationists and Baptists who are not. Any large group will contain a diversity of beliefs and opinions.

Table 1 is at best a generalization. Yet even with all of the above qualifications noted, it seems clear that acceptance of evolution as being compatible with faith is a majority, and not a minority, view among Christians (as represented by their denominations), even in the United States. The numbers "for" and "against" are close, and if Catholics and Episcopalians are excluded, then the number of non-accepting groups (Christians) in the U.S. is larger. Even so, these numbers dispel the myth that it is all Christians, or even a clear majority, that are opposed to teaching evolution or feel that it is in conflict with their faith. Furthermore, within the Protestant denominations, the "mainstream" organized denominations (Methodist, Lutheran, Presbyterian) that have large, well-established and accredited seminaries are accepting of evolution, and it is mostly the smaller, more autonomous, groups, such as those within the Pentecostal movement, where formal education of ministers and church leaders is not highly valued, that do not. Perhaps this is not surprising. According to geneticist Dr. William Thwaites (San Diego State University, now retired), writing about the evolution of creationism on behalf of the National Center for Science Education, "It is a littleknown fact that Methodists, Presbyterians, Lutherans, the United Church of Christ, and many other denominations do not believe that Creation occurred literally as described in Genesis. In fact, the majority of Christian seminaries do not teach a Biblical literalist creation. In the United States and Canada, one tends to find Biblical literalist beliefs being promoted most strongly in small, independent denominations, where it is not uncommon for the leader to have little or no formal theological training." (Thwaites 2000). The exception is the very large Southern Baptist Convention, a well-organized denomination with a very large membership that is against compatibility.

These data could be helpful in teaching evolutionary biology by dispelling the myth that persons of faith, and specifically Christians in the United States, are opposed to it on religious grounds. Although the number of Christians opposed to the idea that evolution is compatible with their faith is still quite large-again, as represented by their organizing bodies and/or spokespersons rather than surveys of individuals (but see Mazur 2004) - the position that evolution is somehow contrary to the Christian faith is a minority one. If non-trinitarian numbers are included (Unitarian Universalists, Church of Jesus Christ of Latter
Day Saints [Mormonism]), the numbers are even more obviously in favor of acceptance/compatibility.

Beyond these figures, a more interesting and more telling statistic is that, within a denomination, it appears that at least in some cases it is the more theologically educated leaders (pastoral staff) who accept evolution, more so than the less educated members at large. One example of this was the 1998 survey of the Presbyterian Church USA, where the statement "evolutionary theory is compatible with the idea of God as Creator" was agreed to by only $61 \%$ of the general membership but by $85 \%$ of the pastors. ${ }^{7}$ It would be interesting to see if this pattern holds true for the other mainstream Protestant denominations. If so, it would allow the following, and rather strong, argument to be made: Among Christians, those who have received a deeper theological education are more likely to understand evolution as being compatible with their faith. In the absence of additional studies for other denominations, such a statement is currently premature, although I am also unaware of any data that would contradict it.

Acknowledgments I sincerely thank Sue Martin, Eugenie Scott, and Kirk Fitzhugh for helpful comments on the manuscript. I am also indebted to Glenn Branch and three anonymous reviewers for their suggestions to improve it. This paper is in part an expansion of a chapter in an upcoming book: Martin, J. W. 2010. The Prism and the Rainbow: A Christian Explains Why Evolution Is Not a Threat. Baltimore, MD: Johns Hopkins University Press.

Note added in proof The following figures for the largest 25 U.S. churches by membership, from the most recent (2010) version of the Yearbook of American and Canadian Churches (published by the National Council of Churches) and rounded to the nearest thousand, came to my attention while this paper was in press: Catholic Church (68.115 million), Southern Baptist Convention (16.228 million), United Methodist Church (7.854 million), Church of Jesus Christ of Latter Day Saints (5.974 million), Church of God in Christ (5.5 million), National Baptist Convention USA (5.0 million), ELCA (4.634 million), National Baptist Convention of America (3.5 million), Assemblies of God (2.9 million), PCUSA (2.845 million), AME (2.5 million), National Missionary Baptist Convention of America

\footnotetext{
${ }^{7}$ The November 1998 PCUSA survey on Science, Technology, and Faith (as reported in The Presbyterian Panel) found that the statement "evolutionary theory is compatible with the idea of God as Creator" was agreed to by $61 \%$ of church members and $85 \%$ of Presbyterian pastors. A more recent (2004) statement from the PCUSA Office of Theology and Worship, issued "in light of recent developments regarding the teaching of the Theory of Evolution in public schools," reiterated the Presbyterian Church U.S. 1969 General Assemblyapproved statement on the subject: "Neither Scripture, our Confession of Faith, nor our Catechisms, teach the Creation of man by the direct and immediate acts of God so as to exclude the possibility of evolution as a scientific theory" (from PCUSA GA Minutes 1969: 5962 , on the PCUSA website at www.pcusa.org/theologyandworship/ science/evolution.htm). See also "Evolution Not an Option: It is Essential to Faithfulness" (SciTech, vol. 9, no. 2, 2000), by James B. Miller, then-President of the Presbyterian Association on Science, Technology, and the Christian Faith.
} 
(2.5 million), Progressive National Baptist Convention (2.5 million), Lutheran Church-Missouri Synod (2.337 million), Churches of Christ (1.639 million), Greek Orthodox Archdiocese of America (1.5 million), Pentecostal Assemblies of the World (1.5 million), AME-Zion Church (1.4 million), American Baptists Churches in the USA (1.331 million), Baptist Bible Fellowship International (1.2 million), Jehovah's Witnesses (1.114 million), United Church of Christ (1.112 million), Church of God (Cleveland) (1.072 million), Christian Churches and Churches of Christ (1.072 million). These figures do not change the major conclusions in this paper. The totals at the bottom of Table 1 would become (left to right) 90.86, 42.74, and 7.50 million, although the addition of two Baptist groups (NMBCA, PNBC) and one Pentecostal group (PAOTW) not treated by me likely would increase the number of denominations (and implied members) in the "non-accepting" category.

\section{References}

Adherents.com. Religious bodies of the world with at least 1 million adherents; 2010. http://www.adherents.com. Accessed 26 January 2010.

ARIS (American Religious Identity Survey) conducted in 2001, sample size of 50,000 Americans, City University of New York;
2010. http://www.gc.cuny.edu/faculty/research_briefs/aris/ aris index.htm. Accessed 4 January 2010.

Barrett $\overline{D B}$, Kurian GT, Johnson TM, editors. World Christian encyclopedia, 2nd edition: a comparative survey of churches and religions in the modern world. Vol. I: the world by countries: religionists, churches, ministries. New York: Oxford University Press; 2001.

Curry A. Creationist beliefs persist in Europe. Science. 2009;323:1159.

Martin JW. The prism and the rainbow: a Christian explains why evolution is not a threat. Baltimore: Johns Hopkins University Press; 2010.

Mazur A. Believers and disbelievers in evolution. Polit Life Sci. 2004;23(2):55-61.

Numbers RL. The creationists: from scientific creationism to intelligent design, expanded edition. Cambridge: Harvard University Press; 2006.

Pew Research Center for the People and the Press (Pew Forum on Religion and Public Life): Americans Struggle with Religion's Role at Home and Abroad; 2002. http://pewforum.org/publications/ reports/poll2002.pdf. Accessed 22 February 2010.

Sager C. Voices for evolution. 3rd ed. Berkeley: National Center for Science Education; 2008.

Thwaites W. Brief history of creationism - from the Middle Ages to "creation science"; 2000. http://ncse.com/creationism/general/ brief-history-creationism. Accessed 28 February 2010. 